\title{
Perancangan Alat Bantu Memanen Karet Ergonomis Guna Mengurangi Resiko Musculoskeletal Disorder Menggunakan Metode RULA dan EFD
}

\author{
Anwardi $^{1}$, Muhammad Ikhsan ${ }^{2}$, Nofirza $^{3}$, Harpito $^{4}$, Ahmad Mas'ari $^{5}$ \\ 1,2,3,4,5 Jurusan Teknik Industri, Fakultas Sains dan Teknologi, UIN Sultan Syarif Kasim Riau \\ Jl. HR. Soebrantas KM. 18 No. 155 Simpang Baru, Panam, Pekanbaru, 28293 \\ Email: anwardi@.uin-suska.ac.id
}

\begin{abstract}
ABSTRAK
Proses pemanenan karet di Pulau Punjung masih dilakukan secara manual dengan dimulai dari aktivitas penyadapan hingga poses pemanenan, dapat diketahui proses pemanenan dapat berpotensi menyebabkan keluhan dan cedera pada peresendian (MsDs). Penelitian ini bertujuan untuk menghasilkan alat bantu pemanenan karet yang dapat mengurangi keluhan dan cedera pada pekerja saat melakukan proses pengambilan lateks dari mangkok. Metode yang digunakan adalah Ergonomic Function Deployment (EFD) untuk mengetahui kriteria dan dimensi alat yang sesuai denga kebutuhan pekerja dan diuji dengan mengunakan metode Rapid Upper Limb Assessment (RULA). Hasil penelitian menunjukan bahwa alat hasil rancangan dapat menurunkan keluhan pada aktivitas menjangkau karet dari level action level-3 menjadi action level-2, sedangkan untuk aktivitas pencongkelan karet dari level action-4 menjadi level action level-2. Hal ini terjadi karena alat hasil rancangan memeiliki dimensi panjang $36 \mathrm{~cm}$ dan lebar $16 \mathrm{~cm}$ yang dapat memperbaiki cara posisi kerja lebih ergonomi.
\end{abstract}

Kata Kunci: EFD, Memanen Karet, RULA

\section{Pendahuluan}

Karet (Hevea Brasiliensis) merupakan komoditi yang mempunyai hubungan erat dengan kebutuhan sehari-hari manusia. Hasil olahan yang menggunakan bahan dasar karet 73 persennya berupa ban, sedangkan sisanya dalam bentuk alat kesehatan, mainan anak-anak, peralatan otomotif, sol sepatu sandal dan sebagainya (Hendratno, 2008).

Industri karet sudah berkembang pesat khususnya Sumatera Barat dan menjadi salah satu sumber pendapatan bagi masyarakat maupun pemerintah, berdasarkan data Badan Pusat Statistik 2017 tercatat bahwa luas perkebunan karet di Sumatera Barat mencapai 141.131 Ha. Kabupaten Dharmasraya adalah kabupaten yang ada di Sumatera Barat yang memiliki luas perkebunan karet terbesar diantara 19 kabupaten lainnya yaitu mencapai 33,890 Ha dan mayoritas penduduknya bekerja sebagai petani karet. Daerah penghasil karet di Kabupaten Dharmasraya adalah Kecamatan Pulau Punjung yang memiliki luas perkebunan mencapai 5,609 Ha (Badan Pusat Statistik, 2017).

Seiring bertambahnya lahan karet di kecamatan Pulau Punjung hingga mencapai 70\% di sektor pertanian karet, maka pada saat ini petani karet yang ada di Pulau Punjung mulai kewalahan dalam proses pemanenan. Proses memanen karet saat ini masih dilakukan secara manual dengan posisi kerja membungkuk saat menjangkau mangkok dan proses pencongkelan karet dari mangkok masih menggunakan tangan tanpa menggunakan alat bantu dan pelindung. Kondisi kerja seperti ini berpotensi akan menyebabkan cedera pada otot pinggang, punggung, pergelangan tangan dan sendi pada jari yang bisa mengakibatkan kelelahan dan cedera atau disebut Musculoskeletal Disorders (MSDs). Pekerjaan mengangkat dan menurunkan suatu barang yang dilakukan secara langsung dan berulang-ulang tanpa bantuan alat apapun dapat menjadi faktor yang berisiko besar terhadap pekerja seperti pegal dan nyeri pada bagian tubuh yang beraktivitas yaitu pada pinggang dan tangan (Wahyu. k, 2010).

Berdasarkan hasil wawancara dengan petani karet, terdapat beberapa masalah dalam proses memanen yaitu, sulitnya menjangkau karet sehingga dapat mengakibatkan cedera otot punggung dan pinggang kemudian sulitnya mengambil karet yang sudah menempel di dalam cawan sehingga petani karet sering mengalami cedera pada jari seperti keseleo bahkan luka yang disebabkan adanya benda keras di dalam karet seperti ranting kayu dan benda keras lainnya, selain itu terdapat keluhan pada bagian pergelangan tangan yang disebabkan karena kelelahan pada bagian otot, terkadang setelah melakukan pemanenan petani merasa selalu mengalami keram pada bagian lengan.

Penelitian awal dilakukan dengan menyebarkan kuesioner Nordic Body Map kepada 
petani karet untuk mengetahui keluhan apa saja yang dirasakan selama melakukan pemanenan karet dan melakukan analisa menggunakan metode Rapid Upper Limb Assissment (RULA) digunakan untuk mengetahui menilai posisi kerja yang dilakukan oleh tubuh bagian atas. Pembagian kuesioner NBM ini bertujuan untuk mengetahui keluhan-keluhan apa saja yang dirasakan petani karet selama menjalankan pekerjaannya, dimana kuesioner ini dibagikan kepada 20 petani karet.

Berdasarkan kuisioner NBM diperoleh hasil yaitu tingkat keluhan sakit dengan presentase 55\% terdapat pada bagian lengan bawah kanan, kemudian presentase $70 \%$ terdapat pada bagian pinggang, punggung, lengan dan pergelangan tangan. Untuk bagian yang sangat sakit dengan presentase $5 \%$ yaitu pada pinggang, lengan bawah kanan, pergelangan tangan kiri, dan tangan kanan. Sedangkan presentase $10 \%$ terdapat pada bagian pergelangan tangan kiri dan punggung sedangkan untuk persentase yang tertinggi mencapai $15 \%$ terdapat pada bagian pergelangan tangan kanan.

Setelah mengetahui keluhan yang dirasakan oleh petani karet selanjutnya di lakukan analisa postur tubuh bagian atas petani menggunakan metode Rapid Upper Limb Assissment (RULA) yaitu pada saat proses penjangkauan karet dan pencongkelan karet seperti gambar berikut:

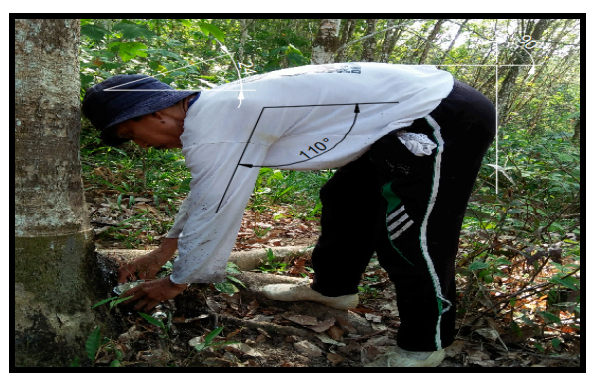

Gambar 1. Kegiatan menjangkau karet

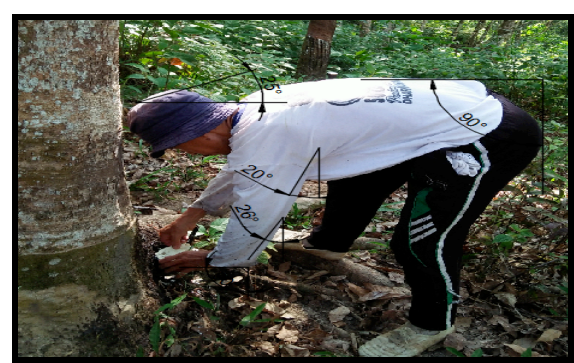

Gambar 2. Kegiatan mencongkel karet

Berikut adalah tabel hasil pengolahan data metode RULA yang telah dilakukan beberapa tahapan.

Tabel 1. Grand Score RULA

\begin{tabular}{c|c} 
Score & Score Group B \\
\hline
\end{tabular}

\begin{tabular}{c|c|c|c|c|c|c|c}
\hline Group $\boldsymbol{A}$ & $\mathbf{1}$ & $\mathbf{2}$ & $\mathbf{3}$ & $\mathbf{4}$ & $\mathbf{5}$ & $\mathbf{6}$ & $\mathbf{7 +}$ \\
\hline $\mathbf{1}$ & 1 & 2 & 3 & 3 & 4 & 5 & 5 \\
\hline $\mathbf{2}$ & 2 & 2 & 3 & 4 & 4 & 5 & 5 \\
\hline $\mathbf{3}$ & 3 & 3 & 3 & 4 & 4 & 5 & 6 \\
\hline $\mathbf{4}$ & 3 & 3 & 3 & 4 & 4 & 5 & 6 \\
\hline $\mathbf{5}$ & 4 & 4 & 4 & 5 & $\mathbf{6}$ & 7 & 7 \\
\hline $\mathbf{6}$ & 4 & 4 & 5 & 6 & 6 & 7 & 7 \\
\hline $\mathbf{7}$ & 5 & 5 & 6 & 6 & 7 & 7 & 7 \\
\hline $\mathbf{8}+$ & 5 & 5 & 6 & 7 & 7 & 7 & 7 \\
\hline
\end{tabular}

Hasil skor dari Tabel 1 tersebut diklasifikasikan ke dalam beberapa kategori level resiko pada Tabel 2 .

Tabel 2. Kategori Level RULA

\begin{tabular}{ccc}
\hline Score & Level resiko & Tindakan \\
\hline $1-2$ & Minimum & Aman \\
\hline $3-4$ & Kecil & Diperlukan Beberapa waktu Kedepan \\
\hline $5-6$ & Sedang & Tindakan dalam waktu dekat \\
\hline 7 & Tinggi & Tindakan sekarang juga \\
\hline
\end{tabular}

Berdasarkan Tabel 2 maka skor akhir dari penilaian RULA pada 2 Kegiatan yaitu:

1. Menjangkau Karet mememliki Skor akhir 6 masuk ke Action Level 3 (sedang). Pada kegiatan ini perlu dilakukan tindakan dalam waktu dekat untuk melakukan suatu perubahan dalam melakukan menjangkau karet.

2. Mencongkel Karet mememliki Skor akhir 7 masuk ke Action Level 4 (tinggi). Pada kegiatan ini perlu dilakukan tindakan perancangan alat sekarang juga, agar tidak terjadi suatu kesalahan fatal saat melakukan pencongkelan karet dan memudahkan petani dalam melaksanakan proses memanen.

Dapat dilihat dari analisis NBM dan RULA ini bahwasannya perlu dilakukan tindakan perancangan alat, agar tidak terjadi suatu kesalahan fatal saat melakukan pemanenan karet dan memudahkan petani dalam melaksanakan proses memanen, apabila kegiatan ini terus dilakukan tanpa ada alat bantu sedikitpun maka besar resiko cedera yang akan terjadi, untuk itu perlu dilakukan kajian lebih lanjut tentang metode kerja dan fasilitas yang digunakan oleh petani dengan mengacu kepada kaedah ergonomi.

\section{Karet}

\section{Tinjauan Pustaka}

Tanaman karet (Hevea brasiliensis) termasuk dalam family Euphorbiacea, disebut dengan nama lain rambung, getah, gota, kejai ataupun hapea, Tanaman ini merupakan penghasilkan metabolit sekunder berupa getah (lateks). Pemanfaatan getah banyak digunakan dalam dunia industri misalnya sebagai bahan pembuat ban kendaraan, bola, sarung tangan, dan peralatan lainnya. Indonesia merupakan 
negara penghasil dan pengekspor karet alam terbesar nomor 2 setelah Thailand (Dewi, 2014).

\section{Lateks}

Lateks adalah partikel karet yang dilapisi oleh protein dan fosfolipida yang terdispersi di dalam serum. Protein terdapat pada lapisan luar memberi muatan negatif terhadap partikel karet pada $\mathrm{pH}$ netral. Pada proses pengolahan karet terdapat tahapan penggumpaan lateks. Penggumpalan lateks dapat terjadi karena rusaknya kemantapan sistem koloid lateks. Kerusakan ini dapat terjadi dengan jalan penetralan muatan protein dengan penambahan asam sehingga muatan negatif dan muatan positif seimbang (Muis, 2007).

Lateks yang baru disadap dari kebun umumnya bersifat tidak stabil atau cepat mengalami penggumpalan atau disebut prakoagulasi dari berbentuk kental hingga menggumpal atau membeku. Prakoagulasi dapat terjadi karena kemantapan bagian koloidal yang terkandung di dalam lateks berkurang akibat aktivitas bakteri, guncangan serta suhu lingkungan yang terlalu tinggi. Bagian-bagian koloidal yang berupa partikel karet ini kemudian menggumpal menjadi satu dan membentuk komponen yang berukuran lebih besar, membeku dan keras seingga pada saat proses memanen petani mengalami kesulitan dam mencongkelnya (Januar dkk, 2016).

\section{Memanen Karet Atau Lateks}

Memanen karet atau biasa disebut dengan pengutipan lateks merupakan suatu kegiatan pencongkelan karet yang sudah menggumpal (Prakoagulasi) pada tempurung dan di ambil dengan menggunakan tangan kemudian dimasukkan ke dalam tong dan dibawa ketempat pengumpulan untuk dilakukan tahap selanjutnya.

Proses dan bentuk postur kerja yang dilakukan petani saat memanen karet yang sudah menggumpal (prakoagulasi) bahkan petani melakukan proses pemanenan dengan posisi membungkuk untuk menjangkau karet, dengan demikian apabila dilakukan secara berulang-ulang maka dapat menimbulkan resiko cedera otot atau disebut Musculosceletal terutama pada pinggang, punggung, pergelangan tangan dan sendi pada jari.

\section{Ergonomi}

Nordic Body Map (NBM) merupakan metode yang digunakan untuk menilai tingkat keparahan (severity) atas terjadinya gangguan atau cedera pada otot-otot. NBM juga merupakan metode penilaian yang sangat subjektif, artinya keberhasilan aplikasi metode ini sangat tergantung dari kondisi dan situasi yang dialami pekerja pada saat dilakukannya penilaian dan juga tergantung dari keahlian dan pengalaman observer yang bersangkutan.Namun demikian, metode ini telah secara luas digunakan oleh para ahli ergonomic untuk menilai tingkat keparahan (Desi, 2014).

\section{Musculoskeletal Disorder (MSD)}

Muskuloskeletal adalah keluhan sakit, nyeri pegal-pegal pada bagian-bagian otot skeletal yang dirasakan oleh seseorang mulai dari keluhan sangat ringan sampai sangat sakit. Apabila otot menerima beban statis secara berulang dan dalam waktu yang lama,akan dapat menyebabkan keluhan berupa kerusakan pada sendi, ligamen dan tendon. Keluhan hingga kerusakan inilah yang biasanya diistilahkan dengan keluhan musculoskeletal disorders (MSDs) (Tarwaka, 20024 dikutip oleh Nur, 2019).

Secara garis besar keluhan otot dapat dikelompokkan menjadi dua yaitu (Mas'idah dkk, 2009):

1. Keluhan sementara (reversible) yaitu keluhan otot yang terjadi pada saat otot menerima beban statis, namun demikian keluhan tersebut akan segera hilang apabila pembebanan dihentikan.

2. Keluhan menetap (persistent) yaitu keluhan otot yang bersifat menetap, walaupun pembebanan kerja telah dihentikan, namun rasa sakit pada otot terus berlanjut.

\section{Nordic Body Map (NBM)}

Nordic Body Map (NBM) merupakan metode yang digunakan untuk menilai tingkat keparahan (severity) atas terjadinya gangguan atau cedera pada otot-otot. NBM juga merupakan metode penilaian yang sangat subjektif, artinya keberhasilan aplikasi metode ini sangat tergantung dari kondisi dan situasi yang dialami pekerja pada saat dilakukannya penilaian dan juga tergantung dari keahlian dan pengalaman observer yang bersangkutan.Namun demikian, metode ini telah secara luas digunakan oleh para ahli ergonomic untuk menilai tingkat keparahan (Desi, 2014).

\section{Metode Penilaian Postur Tubuh RULA}

Penilaian postur kerja diperlukan ketika didapati bahwa postur kerja pekerja memiliki risiko menimbulkan musculosceletal disorder yang diketahui secara visual atau melalui keluhan dari pekerja itu sendiri. Dengan adanya penilaian dan analisis perbaikan postur kerja, diharapkan dapat diterapkan untuk mengurangi atau menghilangkan resiko cedera musculosceletal yang dialami pekerja (Ariani, 2010).

Rapid Upper Limb Assessment (RULA) merupakan suatu metode penelitian untuk menginvestigasi gangguan pada anggota badan. Metode ini dirancang oleh Lynn Mc Atamney dan 
Nigel Corlett (1993) yang menyediakan sebuah perhitungan tingkatan beban musculosceletal di dalam sebuah pekerjaan yang memiliki resiko pada bagian tubuh dari perut hingga leher atau anggota badan lainnya (Ariani, 2010).

Metode ini tidak membutuhkan peralatan spesial dalam penetapan penilaian postur leher, punggung, dan lengan atas. Setiap pergerakan di beri skor yang telah ditetapkan. RULA dikembangkan sebagai suatu metode untuk mendeteksi postur kerja yang merupakan faktor resiko. Metode didesain untuk menilai para pekerja dan mengetahui beban musculosceletal yang kemungkinan menimbulkan gangguan pada anggota badan atas (Ariani, 2010).

\section{Ergonomic Function Deployment (EFD)}

Ergonomic Function Deployment (EFD) merupakan pengembangan dari Quality Function Deployment (QFD) yaitu dengan menambahkan hubungan baru antara keinginan konsumen dan aspek ergonomi dari produk (Ulrich \& Eppinger, 1995). Hubungan ini akan melengkapi bentuk matrik house of quality yang juga menterjemahkan ke dalam aspek-aspek ergonomi yang diinginkan. Matrik House OfQuality yang dikembangkan dan digunakan pada Ergonomi Function Deployment.

\section{Langkah-Langkah Metode Ergonomic Function Deployment (EFD)}

1.PenentuanAtribut Atribut yang digunakan berdasarkan aspek ergonomi,yaitu Efektif, Nyaman, Aman, Sehat, dan Efisien (ENASE).

2. Perancangan Kuesioner Kuesioner digunakan untuk mengetahui kebutuhan-kebutuhan petani.

3. Pembentukan House Of Ergonomic

Matriks house of ergonomi yang digunakan dibentuk sesuai kebutuhan dan keinginan konsumen yang sesuai dengan prinsip-prinsip ergonomi yang dijadikan atribut produk alat memanen karet dan spesifikasi teknik produk alat memanen karet.

\section{Metode Penelitian}

Metode yang digunakan dalam penelitian ini adalah metode Rapid Upper Limb Assessment (RULA) dan metode Ergonomic Function Deployment (EFD).

\section{DataKuesioner EFD}

\section{Hasil dan Pembahasan}

Dalam penelitian ini, pengumpulan data kuesionerdilakukan melalui dua tahap, yaitu: a.Pengumpulan Data Kuesioner Awal

Pada tahap ini dilakukan survey pendahuluan dengan membagikan kuesioner kepada 20 responden secara non acak, yaitu responden petani karet. Kuesioner awal ini dibagikan dengan tujuan untuk mengetahui kebutuhan responden terhadap alat bantu memanen karet. Hasil rekapitulasi dari kuesioner tersebut yaitu:

a. Sebanyak $99 \%$ responden menyatakan proses memanen saat ini membutuhkan waktu yg lama

b. Sebanyak 99\% responden belum merasa nyaman dengan proses memanen karet saat ini

c. Sebanyak $90 \%$ responden memiliki jenis keluhan nyeri sendi setelah melakukan proses memanen

d. Sebanyak $90 \%$ responden memiliki jenis keluhan yang terjadi pada punggung, pinggang, tangan dan leher setelah melakukan proses memanen

e. Sebanyak 99\% responden menyatakan menginginkan posisi berdiri saat memanen karet

f. Sebanyak $95 \%$ menyatakan bahwa responden membutuhkan alat bantu memanen karet.

g. Sebanyak $95 \%$ menyatakan bahwa responden menginginkan alat bantu memanen karet berbentuk tongkat atau sejenisnya untuk bisa menjangkau dan mencongkel karet

Dengan mengetahui rekomendasi dari para responden mengenai alat bantu memanen karet ergonomis untuk mengurangi resiko cedera pada postur tubuh yang bersangkutan.Penulis juga menerima beberapa saran dari responden mengenai alat memanen karet, yaitu dari beberapa saran tersebut yang penulis ambil adalah produk yang dihasilkan dapat meningkatkan waktu pekerjaan lebih cepat dan pastinya alat tersebut memiliki harga yang terjangkau.

Setelah didapatkannya hasil dari kuesioner awal yang dibagikan ke 20 responden ini maka hasilnya akan dapat digunakan sebagai bahan pertimbangan pembuatan pernyataanpada kuesioner yang selanjutnya.

\section{Analisis Implementasi EFD}

Implementasi metode EFD digunakan untuk menetapkan target yang akan dicapai oleh karakteristik teknik produk sehingga dapat mewujudkan kebutuhan konsumen.

\section{Menentukan Tingkat Kepentingan Konsumen}

Tingkat kepentingan konsumen ditentukan dari kuesioner dimana responden diminta untuk memilih 5 kriteria jawaban yaitu sangat tidak penting, tidak penting, cukup penting, penting dan sangat penting. Kelima kriteria jawaban daripernyataan-pernyataan yang diolah lebih lanjut dalam metode EFD. Dari 24 petanyaan tersebut didapatkan hasil dari kepentingan konsumen dengan nilai skor yang berbeda-beda yaitu skor tertinggi yaitu 4,83 terdapat pada pertanyaan "Seberapa penting Alat memanen karet dapat 
memudahkan menjangkau leteks saat berdiri tegak".

\section{Menentukan Tingkat Kepuasan Konsumen}

Setelah mengetahui kepentingan konsumen maka selanjutnya kita harus mengetahui tingkat kepuasan konsumen terhadap proses kegiatan memanen sebelumnya. Tingkat kepuasan konsumen (customer satisfaction performance) merupakan tanggapan konsumen mengenai sejauh mana suatu produk atau jasa dapat memenuhi kebutuhan konsumen, apakah sesuai dengan harapan konsumen atau tidak. Pernyataan yang diberikan sama dengan penilian tingkat kepentingan, para responden diminta untuk memilih 5 kriteria jawaban yang diberi bobot nilai menggunakan skala likert 1 sampai 5, dari 24 petanyaan tersebut didapatkan hasil dari kepuasan konsumen dengan nilai skor yang berbeda-beda yaitu skor tertinggi yaitu 2,09 terdapat pada pertanyaan "Alat memanen karet mudah dibawa".

\section{Menentukan Goal (Target)}

Nilai Goal ditetapkan untuk menunjukkan sasaran yang ingin dicapai peneliti, yaitu dengan menilai seberapa jauh peneliti ingin memenuhi kebutuhan konsumen dengan pertimbangan apakah kebutuhan konsumen tersebut dapat terpenuhi atau tidak. Penetapan nilai Goal dilakukan dengan memperhatikan nilai tingkat kepentingan dan tingkat kepuasan konsumen menggunakan skala 1 sampai 5. Berdasarkan hasil yang diperoleh nilai tertinggi dari goal (target) yaitu sebesar 4,83 untuk variabel Alat memanen karet dapat memudahkan menjangkau leteks saat berdiri tegak. Kemudian untuk variabel terendah didapatkan nilai goal sebesar 4,06 yaitu Alat memanen karet mudah dibersihkan.

\section{Menentukan Rasio Perbaikan (Improvement Ratio)}

Rasio perbaikan (improvement ratio) menunjukkan seberapa besar usaha yang harus dilakukan oleh perusahaan untuk mencapai Goal. Untuk nilai yang semakin besar menunjukkan semakin besar tingkat perubahan yang harus dilakukan. Berdasarkan hasil yang diperoleh nilai tertinggi dari improvement ratio yaitu sebesar 2,47 untuk variabel Alat memanen karet dapat memudahkan menjangkau lateks saat berdiri tegak. Kemudian untuk variabel terendah didapatkan nilai improvementratio sebesar 1.77 yaitu Alat memanen karet mudah dibawa.

\section{Menentukan Titik Jual (SalesPoint)}

Titik jual (sales point) menunjukkan seberapa besar pengaruh pemenuhan kebutuhan konsumen terhadap produk. Penetapan nilai Sales Point didasarkan pada nilai tingkat kepentingan seperti yang dijelaskan pada halaman sebelumnya. Berikut nilai sales poin:

Tabel 3. Nilai sales point

\begin{tabular}{|c|c|}
\hline Nilai & Arti \\
\hline 1 & Tidak ada sales point \\
\hline 1.2 & Sales point sedang \\
\hline 1.5 & Sales point kuat \\
\hline
\end{tabular}

Pada Tabel dapat diketahui bahwasannya alat memanen karet ini sangat dibutuhkan oleh petani untuk memanen karet guna untuk mempermudah petani dalam proses memanen karet, mempercepat waktu pemanenan serta dapat mengurangi resiko cedera. Hal ini dapat dipastikan Sales Point terhadap alat memanen karet ini sangatlah kuat yaitu dengan nilai 1,5 serta hasil ini didapatkan berdasarkan tingkat kepentingan konsumen terhadap alat memnen karet.

\section{Menentukan Raw Weight}

Nilai raw weight merupakan nilai tingkat kepentingan secara menyeluruh (overall importance) dari kebutuhan konsumen. Besar nya nilai raw weight diperoleh dari perkalian tingkat kepentingan konsumen, rasio perbaikan dan sales point. Semakin besar raw weight maka semakin penting kebutuhan tersebut untuk dipenuhi. Berdasarkan hasil yang diperoleh nilai tertinggi dari Raw Weight yaitu sebesar 17,89 untuk variabel alat memanen karet dapat memudahkan menjangkau leteks saat berdiri tegak Kemudian untuk variabel terendah didapatkan nilai Raw Weightsebesar 9,87 yaitu Alat memanen karet mudah dibawa.

\section{Menghitung Normalized Raw Weight}

Perhitungan normalized raw weight merupakan nilai raw weight yang dibuat dalam skala 0 sampai 1 atau dalam persen. Berdasarkan hasil yang diperoleh nilai tertinggi dari normalized raw weight yang didapatkan dari pengolahan data Tingkat Kepentingan Improvement ratio, Sales Point, Raw Weight yaitu sebesar 0,049 untuk variabel Alat memanen karet dapat memudahkan menjangkau lateks saat berdiri tegak. Kemudian untuk nilai nyang terendah didapatkan nilai normalized raw weight sebesar 0,027 yaitu Alat memanen karet mudah dibawa.

\section{Menentukan Respon Teknis}

Langkah selanjutnya yaitu menentukan respon teknis. Respon teknis ini berisi tentang penerjemahan selera konsumen dalam bentuk istilah teknis. Menunjukkan rencana-rencana atau rancangan usaha teknis dalam mewujudkan kebutuhan

\section{Hubungan Respon Teknis dengan Kebutuhan Konsumen}


Pada metode EFD digunakan matriks House of Ergonomic, yaitu suatu matriks yang sistematis menggambarkan pendekatan yang dilakukan untuk merancang produk yang berkualitas, mudah dikerjakan, mengidentifikasi karakteristik teknis yang sesuai untuk memenuhi kebutuhan konsumen, terukur dan global. Hubungan antara respon teknis dengan kebutuhan konsumen ditunjukkan dengan simbol yang melambangkan seberapa kuat hubungan diantara keduanya. Semakin banyak suatu elemen pada karakteristik teknis yang berhubungan dengan elemen kebutuhan konsumen berarti elemen-elemen karakteristik teknis tersebut berpengaruhdalam pemenuhan kebutuhan konsumen. Setelah diketahui hubungan antara karakteristik teknis dengan kebutuhan konsumen maka selanjutnya dihitung nilai kontribusi masingmasing karakteristik teknis. Berdasarkan hasil tertinggi nilai Perhitungan Kontribusi dan Urutan Prioritas yaitu sebesar 1.226 untuk variable Alat Memanen Karet Dapat Memudahkan Menjangkau Leteks Saat Berdiri Tegak. Kemudian untuk variable terendah didapatkan nilai yaitu sebesar 0,342 yaitu adanya bonus saat pembelian.

\section{Menentukan TargetSpesifikasi}

Target spesifikasi ini merupakan suatu hasil dari pengembangan karakteristik teknis yang didapat dari identifikasi kebutuhan konsumen. Berikut ini adalah tabel target spesifikasi yang akan dicapai dalam penelitian ini.

Tabel 4. Target Spesifikasi

\begin{tabular}{|c|c|}
\hline Karakteristik Teknis & TargetSpesifikasi \\
\hline $\begin{array}{l}\text { Sesuai dengan ukuran } \\
\text { tubuh }\end{array}$ & Dimensi produk sesuai tubuh petani \\
\hline Ringan dibawa & Ringan saat di bawa \\
\hline Mudah dibersihkan & Produk mudah dibersihkan \\
\hline Aman digunakan & Dapat melindungi tangan dari getah \\
\hline Berbahan kuat & Berbahan baku Kuat \\
\hline Berbahan stainless & Dilapisi Stainsless \\
\hline Mudah menjangkau lateks & $\begin{array}{l}\text { Memudahkan petani menjangkau } \\
\text { lateks beku }\end{array}$ \\
\hline Mudah digunakan & Mudah dioperasikan \\
\hline Meningatkan prodiktivitas & Mempercepat pemanenan \\
\hline Safety & $\begin{array}{l}\text { Dapat mengurangi cedera saat } \\
\text { memanen }\end{array}$ \\
\hline $\begin{array}{l}\text { Ukuran nyaman untuk } \\
\text { operator }\end{array}$ & Nyaman digunakan \\
\hline Kualitas terbaik & Berkualitas \\
\hline Tidak mudah patah & Bahan tidak mudah patah \\
\hline Tidak berkarat & Bahan tidak berkarat \\
\hline Awet dan Tahan lama & Bahan kuat dan awet \\
\hline Mudah diperbaiki & Alat mudah diperbaiki apabila rusak \\
\hline $\begin{array}{c}\text { Mudah menjangkau saat } \\
\text { berdiri tegak }\end{array}$ & $\begin{array}{l}\text { Dapat mengambil karet walaupun } \\
\text { saat berdiri tegak }\end{array}$ \\
\hline Nayaman dipegang & Nyaman saat dipegang \\
\hline Desain mearik & Bentuk produk menarik \\
\hline Warna produk menarik & $\begin{array}{l}\text { Warna yang digunakan tidak } \\
\text { monoton }\end{array}$ \\
\hline Multifungsi & $\begin{array}{l}\text { Bisa digunakan buat lateks beku dan } \\
\text { cair }\end{array}$ \\
\hline Harga kompetitif & $<$ Rp. $350.000,00$ \\
\hline Harga murah & Harga merakyat \\
\hline
\end{tabular}

\begin{tabular}{l|l} 
Tersedia bonus & Memiliki bonus komponen \\
\hline
\end{tabular}

Sumber: Pengolahan data 2019

\section{Data Anthropometri}

Data anthropometri sangat diperlukan dalam merancang suatu produk. Data anthropometri dapat juga menentukan ukuran, bentuk dan dimensi yang sesuai dengan keadaan fisik penggunanya. Di bawah ini adalah data dimensi anthropometri yang digunakan dalam penentuandimensi. Data tersebut diambil Rekap Data baku Antropometri Indonesia (DAI) 2013. Dalam menentukan dimensi produk, dan menyesuaikan dengan dimensi tubuh orang dewasa pada umumnya. Berikut adalah pertimbangan penentuan dimensi dari alat memanen karet yang akan dirancang :

1. Tinggi Alat Memanen

Dalam perancangan alat memanen karet ini tinggi alat diperlukan ukuran yang meliputi Panjang Genggaman Tangan Ke Depan (PGT). Pada pengukuran ketinggian alat ini menggunakan persentil 5 karena agar saat orang menjangkau karet bisa sesuai, baik yang berukuran pendek maupun yang berukuran tinggi dapat menggunakan alat dengan nyaman. Untuk ukuran ketinggian alat presentil 5 yaitu $45.52 \mathrm{~cm}$. maka ketinggian alat memanen karet yang dikehendaki yaitu $40 \mathrm{~cm}$

2. Lebar Alat Memanen

Dalam perancangan alat memanen karet ini lebaralat diperlukan ukuran yang meliputi Lebar Telapak Tangan (LTT). Pada pengukuran lebar alat ini menggunakan persentil 95 karena agar saat orang menjangkau penjepit alat bisa sesuai.. Untuk ukuran lebar alat presentil 95 yaitu $16.17 \mathrm{~cm}$. maka lebar alat memanen karet yang dikehendaki yaitu 16 $\mathrm{cm}$

\section{Perancangan Produk}

Dalam perancangan alat memanen karet ini,terdapat beberapa tahapan, diantaranya:

\section{Penentuan Desain}

Padatahapinidibuatgambarkerjasusunandanga mbarkerjayangnantinyaakandigunakansebagaiinfor masidalamprosesmanufakturjugasebagaibahandala mkebutuhanpartyangdigunakan.Agarmempermu dahdalammelakukanpembuatanalathalyangharus dilakukanterlebihdahulumendesainalatsedemikanr upasehinggapadasaatprosespembuatantelahmengeta huibentukprototypedarialatyangakandibuat sesuai dengan kebutuhan konsumen seperti hasil dari pengolahan data EFD.

\section{Penyelesaian}

Proses penyelesaian adalah tahap akhir dari metode EFD. Berikut ini adalah penjelasan 
mengenai pembuatan alat. Sebelum melakukan pembuatan atau perakitan alat maka disiap kan terlebih dahulu alat yang akan digunakanya itu mesin gerinda potong, mesin bor, mesin las listrik, kunci kombinasi, busur, dan meteran. Bahan yang akan digunakan yaitu besi as, plat besi, baut, mur, per, pengunci tangkai. Proses pembuatan alat memanen dapat dilakuakan dengan tahapan sebagai berikut:

1. Melakukan pengukuran plat rangka besi untuk untuk dijadikan tangkai atau tuas ukuran $23 \mathrm{~cm} \times 2 \mathrm{~cm} \times 0,2 \mathrm{~mm}$, mata penjepit dari besi as ukuran $18 \mathrm{~cm} \times 1,5 \mathrm{~cm} \times 0,5 \mathrm{~cm}$, pelat besi pendorong mangkok ukuran $26 \mathrm{~cm}$ $\mathrm{x} 1,5 \mathrm{~cm}, 0,3 \mathrm{~mm}$, pelat besi penggerak dorongan mangkok ukuran $9 \mathrm{~cm}$ x $1,5 \mathrm{~cm}, 0,3$ $\mathrm{mm}$.

2. Melakukan pemotongan plat besi sesuai ukuran yang ditentukan, pemotongan besi, pemotongan plat besi untuk pendorong mangkok.

3. Pembengkokkan plat besi untuk dijadikan kerangka utama pada alat.

4. Membuat kedudukan pendorong pada tangkai.

5. Pengeboran lubang baut pada plat

6. Menyatukan per didalam tangkai yang berfungsi untuk mengurangi beban saat penjepitan.

7. Pembentukan 4 mata penjepit seperti cakar ayam berukuran $18 \mathrm{~cm}$ x $1,5 \mathrm{~cm} \quad \mathrm{x} \quad 0,5 \mathrm{~cm}$ dengan lengkungan mata $20^{\circ}$ dengan kelonggaran $4 \mathrm{~cm}$

8. Mengebor lubang baut pada tangkai untuk menyatukan mata penjepit dengan tangkai utama

9. Selah disatukan, kemudian membuat pendorong mangkok dengan ukuran $26 \mathrm{~cm}$ x $1,5 \mathrm{~cm}, 0,3$ $\mathrm{mm}$ dan dilobangi pada tengan plat berukuran 6 $\mathrm{cm}$ berfungsi untuk sebagai lintasan penggerak dorongan.

10. Membuat pelat besi penggerak dorongan mangkok ukuran $9 \mathrm{~cm} \times 1,5 \mathrm{~cm}, 0,3 \mathrm{~mm}$

11. Membuat lingkaran bibir pendorong mangkok dengan ukuran diameter 6 menggunakan plat

12. Membengkokkan sisi bawah plat untuk disatukan dengan lingkaran pendorong kemudian disatukan dengan cara di las

13. Kemudian Menyatukannya dengan besi penggerak dorongan pada tangkai

14. Penyatuan semua komponen yang telah dirakit.

15. Setelah komponen dirakit melakukan crome agar alat tidak berkarat.

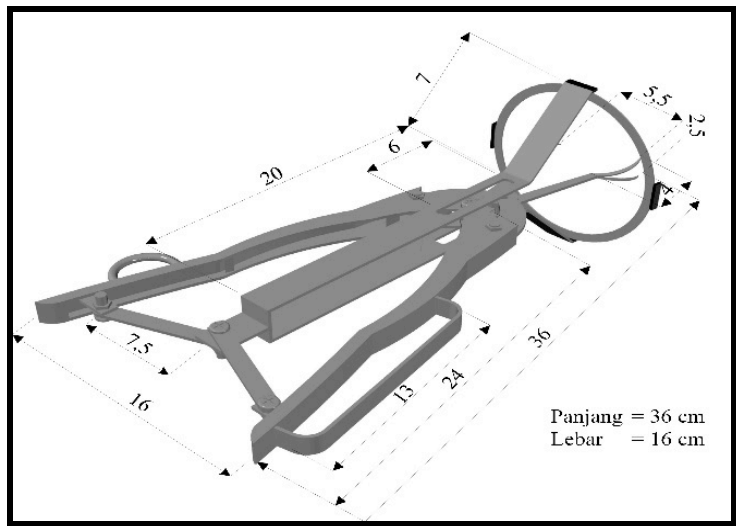

Gambar 3. Desain memanen karet

\section{Kesimpulan}

Berdasarkan pada tujuan penelitian yang telah dirumuskan dan pengolahan data dapat disimpulkan bahwa:

1. Berdasarkan penelitian yang dilakukan dengan menggunakan metode Ergonomic Function Deployment (EFD), variabel yang menjadi prioritas perancangan produk yaitu alat bantu memanen karet ergonomis sehingga dapat memudahkan petani menjangkau karet pada saat berdiri tegak dengan bobot 0,10 , ukuran alat memanen karet nyaman dan sesuai dengan dimensi tubuh antropometri dengan bobot 0,10 dan alat memanen karet dapat melindungi tangan saat memanen karet dengan bobot 0,09. Dimana didapatkan hasil sebuah perancangan alat memanen karet yang ergonomis sesuai kebutuhan petani dengan dimensi $36 \times 16 \mathrm{~cm}$. Dengan panjang alat menggunakan dimensi anthropometri panjang tangan kedepan, lebar alat menggunakan dimensi lebar telapak tangan.

2. Berdasarkan hasil pengolahan data menggunakan metode RULA terdapat perbedaan dari sebelum dan sesudah perancangan, dimana postur tubuh menjangkau karet yang pada awalnya berada ditingkat Action Level ke- 3 yang berarti tinggi beresiko cedera, menjadi tingkat Action Level ke- 2 yang tergolong resiko rendah yang aman, kemudian untuk postur tubuh mencongkel karet yang pada awalnya berada ditingkat Action Level ke 4 yang berarti sangat tinggi beresiko cedera, menjadi tingkat Action Level ke - 2 yang tergolong resiko rendah yang aman. Pada kuisioner nordic body map menujukan pengurangan bagian yang dirasa sangat sakit awalnya 7 bagian menjadi 1 bagian tubuh yang mengalami sangat sakit. Berdasarkan hasil diatas dapat disimpulkan bahwasannya alat memanen karet mampu mengurangi resiko Musculosceletal Disorder. 


\section{Saran}

Beberapa saran untuk dipertimbangkan berkaitan dengan hasil penelitian ini adalah sebagai berikut:

a. Sebaiknya alat memanen karet bisa di setel sesuai dengan kondisi tinggi atau rendahnya mangkok sehingga petani dapat lebih nyaman dalam proses pemanenan karet tanpa ada lagi menyesuaian kondisi ketinggian mangkok.

b. Sebaiknya alat memanen karet dirancang agar bisa menjepit karet dengan sempurna, sehingga karet yang terjepit oleh alat pencongkel tidak terlepas pada saat menekan tuas.

c. Sebaiknya alat memanen karet dirancang bukan hanya untuk orang dewasa saja, melainkan juga bisa digunakan oleh semua kalangan umur yang berdasarkan ukuran postur tubuh .

d. Sebaiknya alat yang dirancang berbobot ringan agar dapat memudahkan petani membawa alat tersebut dalam proses pemanenan.

e. Sebaiknya jarak jangkauan jari pada saat menggenggam tuas tidak terlalu jauh, hal ini petani merasakan kesulitan pada saat menekan tuas

f. Sebaiknya pendorong mangkok bisa lebih jauh dorongannya, sehingga mangkok bisa terlepas dengan cepat pada saat menekan tuas.

\section{Daftar Pustaka}

[1] Hendranto, Absari., 2008. Analisis Permintaan Ekspor Karet Alam Indonesia Di Negara Cina. Bogor: Studi Ekonomi Pertanian Dan Sumberdaya. Institut Pertanian Bogor.

[2] Bambang, 2016. Statistik Perkebunan Indonesia 2015-2017. Jakarta: Direktorat Jendral Perkebunan.

[3] Wahyu., 2010. Pengaruh Teknik Mengangkat Beban Terhadap Nyeri Pinggang Pada Buruh Tani Di Dukuh Plumbon, Desa Sentono, Kecamatan Karang dowo, Kabupaten Klaten Tahun 2010. Surakarta: Universitas Sebelas Maret.

[4] Dewi., 2014. Pemanenan Getah Karet (Hevea brasiliensis Muell. Arg) dan Penentuan Kadar Karet Kering (KKK) dengan Variasi Temperatur Pengovenan di PT. Djambi Waras Jujuhan Kabupaten Bungo, Jambi Jurusan Biologi, Fakultas Sains dan Matematika, Universitas Diponegoro.

[5] Wijaya., Dkk., 2018. Analisa Postur Kerja Dengan Metode Rapid Upper Limb
[6] Akshinta, P,Y,Dkk., 2018. Analisis Rula (Rapid Upper Limb Assessment) Dalam Menentukan Perbaikan Postur Pekerja Las Listrik Pada Bengkel Las Listrik Nur Untuk Mengurangi Resiko Musculoskeletal Disorders. Semarang: Studi Teknik Industri, Fakultas Teknik, Universitas Diponegoro.

[7] Mufti,Dkk., 2013. Kajian Postur Kerja Pada Pengrajin Tenun Songket Pandai Sikek. Padang: Jurusan Teknik Industri, Fakultas Teknologi Industri, Universitas Bung Hatta.

[8] Nur, Muhammad., Ario, D. 2019. Usulan Perbaikan Postur Kerja Aktivitas Pemuatan Barang menggunakan Metode Loading On The Upper Body Assessment (LUBA). Industrial Engineering Journal Vol.8 No.2.

[9] Desi.,2014.Aplikasi Nordic Body Map Untuk Mengurangi Musculoskeletal Disorder Pada Pengrajin Songket. Palembang: Universitas Binadharma.

[10] Mas'idah, Dkk., 2009. Analisa Manual Material Handling (Mmh) Dengan Menggunakan Metode Biomekanika Untuk Mengidentifikasi Resiko Cidera Tulang Belakang (Musculoskeletal Disorder). Fakultas Teknologi Industri UNISSULA, Sultan Agung Vol Xlv No. 119.

[11] Susiono, Dkk., 2012. Perbaikan Postur Kerja Untuk Mengurangi Keluhan Muskuloskeletal Dengan Pendekatan Metode Owas. Teknik Industri, Cilegon : Fakultas Teknik Universitas Sultan Ageng Tirtayasa.

[12] Ariani,, 2010. Analisis postur kerja dalam sistem manusia mesin untuk mengurangi fatigue akibat kerja padabagian air trafficcontrol(atc) dipt. Angkasa pura ii polonia. Medan:Fakultas Teknik USU.

[13] Zulkifli., 2009. Validitas dan Reliabilitas Suatu Instrumen Penelitian. Medan: Pps Unimed Vol. 6.

[14] Astutik, R., 2015. Perancangan Meja Kerja Khusus Recycle Sampah Elektronik Yang Ergonomis Menggunakan Metode Ergonomic Function Deployment (Efd). Semarang: Program Studi Teknik Industri, Fakultas Teknik Universitas Dian Nuswantoro.

[15] Meyharti, Dkk., 2013. Usulan Rancangan Baby Tafel Portable dengan Menggunakan Metode Ergonomic Function Deployment. 
Bandung: Jurusan Teknik Industri Institut Teknologi Nasional (Itenas).

[16] Wahyu., 2012. Desain Sistem Penentuan Kualitas Pelayanan Kesehatan Dengan MenggunakanMetode Quality Function Deployment (QFD) Sebagai Upaya meningkatkanCustomer Satisfaction di Rumah Sakit Banyumanik. Semarang:Universitas Dian Nuswantoro.

[17] Teza, M., 2013. Perancangan Ulang Alat Pembuat Gerabah Yang Ergonomis, Fakultas Sains Dan Teknologi. Pekanbaru : Universitas Islam Negeri Sultan Syarif Kasim Riau.

[18] Suhardi., 2008. Perancangan Sistem Kerja dan Ergonomi Industri Jilid 1. Jakarta: halaman 9.

[19] Tannady, Dkk., 2017. Analisis Postur Kerja Pembuat Gula Srikaya Dengan Metode Quick Exposure Checklist. Jakarta: Studi Teknik Industri, Universitas Bunda Mulia. 